\title{
Regional Cerebral Blood Flow and Cerebral Metabolic Rate of Oxygen during Hyperventilation in the Newborn Dog
}

\author{
JOHN H. REUTER AND THERESA A. DISNEY \\ Division of Neonatology of the Department of Pediatrics, Children's Hospital Research Foundation, University of \\ Cincinnati, Cincinnati, Ohio 45267
}

\begin{abstract}
Cerebral blood flow (CBF) and cerebral metabolic rate of oxygen $\left(\mathrm{CMRO}_{2}\right)$ were measured during normocarbia and during both moderate and severe hypocarbia. Eighteen newborn mongrel dogs, 1 to 7 days of age, were given pancuronium and ventilated with $70 \% \mathrm{~N}_{2} \mathrm{O}$ and $30 \% \mathrm{O}_{2}$. The respirator was adjusted to achieve a $\mathrm{PaCO}_{2}$ of 15 torr, all subsequent changes to 25 and 40 torr were made by adjusting the inspired concentration of $\mathrm{CO}_{2}$. The sequence of $\mathrm{PaCO}_{2}$ levels was randomized. $\mathrm{CBF}$ was measured by microsphere technique and $\mathrm{CMRO}_{2}$ calculated as arterial-sagittal sinus $\mathrm{O}_{2}$ content difference times hemispheric blood flow. All measurements were made after 30 min at each $\mathrm{PaCO}_{2}$. Total $\mathrm{CBF}$ was reduced at a $\mathrm{PaCO}_{2}$ of 25 torr $(p<0.001)$, further reduction in $\mathrm{PaCO}_{2}$ to 15 torr resulted in a significant decrease in total CBF $(p<$ 0.01 ) compared to 25 torr $\mathrm{CO}_{2}$. All regional cerebral blood flows were reduced at a $\mathrm{PaCO}_{2}$ of 25 torr $(p<0.001)$, and most regional CBFs had further significant decreases in flow at a $\mathrm{PaCO}_{2}$ of 15 torr. $\mathrm{CMRO}_{2}$ was $1.28 \pm 0.47 \mathrm{ml} /$ $100 \mathrm{~g} / \mathrm{min}$ at a $\mathrm{PaCO}_{2}$ of 40 torr and fell to $1.09 \pm 0.34(p$ $<0.05)$ and to $1.04 \pm 0.28(p<0.025) \mathrm{ml} / 100 \mathrm{~g} / \mathrm{min}$ at $\mathrm{PaCO}_{2}$ values of 25 and 15 torr, respectively. Cardiac output was calculated to be $169 \pm 71 \mathrm{ml} / \mathrm{kg} / \mathrm{min}$ at a $\mathrm{PaCO}_{2}$ of 40 torr and fell to $135 \pm 27(p<0.025)$ and to $127 \pm$ $36(p<0.005) \mathrm{ml} / \mathrm{kg} / \mathrm{min}$ at $\mathrm{PaCO}_{2}$ values of 25 and 15 torr, respectively. Regression analysis of the relationship between $\mathrm{PaCO}_{2}$ and $\mathrm{CBF}$ for values of $\mathrm{PaCO}_{2}$ between 10 and 50 torr was nonlinear $\left(\ln \mathrm{CBF}=\mathbf{a}+\mathbf{b} \cdot \mathrm{PaCO}_{2}\right) . \mathrm{A}$ series of regression curves for regional $\mathrm{CBF}$ are presented with $R$ values between 0.69 and $0.81(p<0.001)$. It is concluded that hypocarbia to $\mathrm{PaCO}_{2}$ values of 25 and 15 torr results in significant decreases in total as well as regional cerebral blood flows. $\mathrm{CMRO}_{2}$ and cardiac output also show significant decreases at $\mathrm{PaCO}_{2}$ values of both 25 and 15 torr compared to normocarbia. A nonlinear relationship is demonstrated between regional CBF and $\mathrm{PaCO}_{2}$ between 10 and 50 torr. (Pediatr Res 20: 11021106, 1986)
\end{abstract}

\section{Abbreviations}

CBF, cerebral blood flow

$\mathrm{CMRO}_{2}$, cerebral metabolic rate of oxygen

rCBF, regional CBF

CPD, citrate phosphate dextrose

CPM, counts per minute

Received August 21, 1985; accepted June 4, 1986.

All correspondence and reprint request to Dr. John H. Reuter, Department of Pediatrics Newborn Division, University of Cincinnati, College of Medicine, 231 Bethesda Avenue, Cincinnati, OH 45267-0541.

Supported by the Cincinnati Children's Hospital Research Foundation Trustee's Award and NIH RR 00068 CLINFO.
Hypocarbia is a known depressant of $\mathrm{CBF}$ in neonatal animals of several species (1-5). Since hyperventilation, for persistent pulmonary hypertension of the newborn, is a common practice in many intensive care nurseries, concern is raised as to whether decreased oxygen delivery to the brain secondary to decreased CBF during hypocarbia could be of such severity as to cause cerebral hypoxia. In separate studies, both Kennealy et al. (6) and Sugioka and Davis (7) have demonstrated significant decreases in cerebral tissue $\mathrm{PO}_{2}$ during hyperventilation in adult dogs. Similarly, hypocarbia has been shown to increase cerebral venous (8) and CSF lactate levels (9) in dogs and to cause electroencephalographic changes in man (10).

The $\mathrm{CMRO}_{2}$ was reported by Gregoire et al. (11) for newborn dogs during mild hypocarbia. Their value for $\mathrm{CMRO}_{2}$ was not different from that measured during normocarbia but $\mathrm{PaCO}_{2}$ was lowered only to 31 torr. We decided to test the hypothesis that the decrease in CBF during hyperventilation can result in a reduction in the cerebral metabolic rate of oxygen. The current study was therefore designed to measure total and rCBF and total $\mathrm{CMRO}_{2}$ in the newborn dog during normocarbia and during both moderate and severe hypocarbia.

\section{MATERIALS AND METHODS}

Surgery. Eighteen newborn mongrel dogs, 1 to 7 days of age, weighing 265 to $475 \mathrm{~g}$, were removed from the litter on the morning of study. The animals were given an intravenous injection of $0.1 \mathrm{mg} / \mathrm{kg}$ of pancuronium, immediately intubated $(2.5$ 3.0 Portex endotracheal tube) and ventilated (Harvard Rodent Respirator, Harvard Apparatus So. Natick, MA) with $70 \%$ nitrous oxide and $30 \%$ oxygen. A rectal temperature probe was inserted and the animal placed on an electric heating pad and servocontrolled to $37.5^{\circ} \mathrm{C}$. Halothane (1 to $1.25 \%$ ) was administered during surgical procedures which included catheterization of the femoral artery and vein with PE-50 tubing. The femoral artery catheter was advanced to the level of the sternum for aortic pressure monitoring (Statham physiologic pressure transducer, Gould pre-amp and recorder) and procurement of reference flow samples. A left ventricular catheter for injection of microspheres was inserted in the following manner. The left common carotid artery was exposed and elevated onto the blades of an iris forceps. Temporary occlusion occurred at the two sites of contact with the forceps. The $1-\mathrm{cm}$ section of artery between the forcep blades was punctured with a 23-gauge needle and catheterized with a tapered PE-50 catheter which was advanced into the left ventricle. The puncture site was sealed by the catheter and after removal of the forceps a nonligated artery with pulsation proximal and distal to the site of catheter insertion remained. An incision was made over the dorsal skull exposing the sagittal suture. A 22 gauge Jelco catheter (Critikon, Inc., Tampa, FL) was inserted through the sagittal suture into the underlying 
sagittal sinus. The catheter entered the rostral portion of the sinus at the junction of the frontoparietal (coronal) and sagittal suture. The catheter was advanced through the sagittal suture 2 to $4 \mathrm{~mm}$ to obtain a blood return, the plastic sheath was then advanced $2 \mathrm{~mm}$ further after which the metal trochar was withdrawn. Estimated caudal penetration would be 4-6 mm. The hub of the catheter was severed and the indwelling catheter connected to PE-50 tubing with a 23-gauge needle shaft. Sagittal sinus blood samples were slowly withdrawn over a 2-min period to minimize potential changes in sinus pressure. Upon completion of surgery, incision sites were infiltrated with $1 \%$ xylocaine and halothane discontinued, the animal was ventilated with $70 \%$ nitrous oxide and $30 \%$ oxygen for the duration of the study. After surgery, a 1-h period was allowed for the animal to stabilize.

Experimental design. Immediately after completion of surgery the respirator rate was increased to $75 \mathrm{cycle} / \mathrm{min}$ and stroke volume increased to achieve an arterial carbon dioxide tension of 15 torr. Respirator settings remained unchanged for the remainder of the study. Carbon dioxide was immediately bled into the system to achieve a $\mathrm{PaCO}_{2}$ of 40 torr during the one hour period of recovery. All subsequent changes in $\mathrm{PaCO}_{2}$ during the experimental conditions were accomplished by adjusting the inspired carbon dioxide concentration. Peak airway pressure was measured by a manometer, connected by a $\mathrm{T}$-piece near the proximal end of the endotracheal tube.

Measurements of $\mathrm{CBF}$ and $\mathrm{CMRO}_{2}$ were to be made at $\mathrm{PaCO}_{2}$ values of 40,25, and 15 torr. To control for time and possible effects of sequence, the order of experimental periods was randomized. Randomization was achieved by ordering the three experimental periods in every possible combination ( 3 factorial $=6$ ). The six possible sequences were studied in triplicate to arrive at a total of 18 experimental animals.

At the end of the $1 \mathrm{~h}$ recovery, $\mathrm{PaCO}_{2}$ was adjusted to 40,25 , or 15 torr. After $30 \mathrm{~min}$, blood was drawn from the femoral artery and sagittal sinus for blood gas (Radiometer BMS 3, Radiometer America, Louisville, KY), $\mathrm{O}_{2}$ content (Lex- $\mathrm{O}_{2}-\mathrm{Con}$, Woodland Associates, Wrenthem, MA), and hematocrit determinations. Approximately 800,000 $15 \mu$ microspheres (3-M, St. Paul, MN) labeled with $85-\mathrm{Sr}, 51-\mathrm{Cr}$, or $141-\mathrm{Ce}$, were reagitated and flushed into the left ventricle over $30 \mathrm{~s}$ with $2 \mathrm{ml}$ of warmed saline. Aortic reference samples were procured via the femoral catheter by an infusion/withdrawal syringe pump (Harvard Apparatus) at a rate of $1.36 \mathrm{ml} / \mathrm{min}$. The withdrawal pump was started $10 \mathrm{~s}$ prior to microsphere injection and continued for a total of $2 \mathrm{~min}$. After each microsphere injection was complete a replacement transfusion of CPD adult dog donor blood was given. After each experimental period the $\mathrm{PaCO}_{2}$ was returned to 40 torr for $15 \mathrm{~min}$ before proceeding to the next prescribed $\mathrm{PaCO}_{2}$. Upon completion of the third period the animal was sacrificed with pentobarbital and the brain removed, weighed, and placed in $5 \%$ gluteraldehyde. After 7 days, the gross brain was divided into the right and left hemispheres, brainstem and cerebellum; the hemispheres were further dissected into cortical gray matter, subcortical white matter, and thalamus (12). CPM in each sample were determined with a Packard auto $\gamma$ scintillation spectrometer; isotope cross-overs were corrected by simultaneous equations. Blood flow was calculated as tissue blood flow $=$ tissue CPM per $100 \mathrm{~g} / \mathrm{CPM}$ of reference sample $\times$ reference withdrawal rate (13). Cardiac output was calculated as $\mathrm{CPM}$ injected/CPM of reference sample $\times$ reference withdrawal rate. All regional tissue samples had greater than 400 microspheres as recommended by Buckberg et al. (14) and all reference samples contained greater than 7000 microspheres.

Verification of sagittal sinus sampling. The use of sagittal sinus sampling to determine the cerebral metabolic rate of oxygen, or indeed any substance, is based on the assumption that there is no significant drainage of extracerebral venous blood into the sagittal sinus. Any contamination of the sagittal sinus blood with extracerebral venous blood would lead to erroneous calculations of cerebral metabolic rates, particularly during periods of low cerebral blood flow. In the newborn dog, there are significant anastomoses of the distal branches of the maxillary artery with the cerebral arterial circulation (15) which thus preclude the use of intraarterial injections of indicator (Evans Blue) as a method for testing for the presence of extracerebral venous blood in the sagittal sinus. Instead, we chose a modification of the hydrogen polarographic technique as described by Aukland et al. in 1964 (16). Briefly, an electrode polarized to $0.620 \mathrm{mV}$ will accept electrons from $\mathrm{H}_{2}$ thus generating a current which can be amplified and recorded (Hydrogen Flow Monitoring Instrument, Scientific Computer Technology, 1706 Iliff, Cincinnati, OH). If $\mathrm{H}_{2}$ is infiltrated into a region drained by the sagittal sinus, a current will be generated from a sagittal sinus electrode as $\mathrm{H}_{2}$ is washed out of the tissue by the local blood flow.

Four newborn dogs were prepared as previously described except that $20 \mathrm{mg} / \mathrm{kg}$ of pentobarbital was administered due to the more invasive nature of this study. A hydrogen electrode ( 0.004 inches in diameter) was inserted through the sagittal sinus catheter into the sagittal sinus and polarized to $+0.620 \mathrm{mV}$. A silver-silver chloride wire was placed subcutaneously to serve as the reference electrode. Injections of $1.5 \mathrm{ml}$ of normal saline saturated with hydrogen gas was injected during both normocarbia and during hypocarbia into two distinct locations: 1) percutaneous injections into the cerebral hemispheres and 2) subcutaneous injections into the occipital, parietal, frontal, and periorbital regions. Injection of the hydrogen saturated saline into the cerebral hemispheres resulted in an immediate spike (within 15 s) in the hydrogen generated current as recorded from the sagittal sinus electrode during both normo- and hypocarbia. Subcutaneous injections of hydrogen saturated saline resulted in no deviation from baseline in the hydrogen generated current during the subsequent $5 \mathrm{~min}$ of observation during either normo- or hypocarbia. Our interpretation of these findings is that there is no significant drainage of extracerebral venous blood into the sagittal sinus during conditions of normo- or hypocarbia.

Additional studies. In order to more uniformly distribute the data for regression analysis, six additional newborn dogs were studied to generate data points between 15 and 25 torr and between 25 and 40 torr $\mathrm{PaCO}_{2}$. The measurements were made under the exact same conditions as the previous 18 animals. Three microsphere injections were performed in each and a given $\mathrm{PaCO}_{2}$ induced 30 min prior to each $\mathrm{CBF}$ determination. Data from these six animals were combined with the previous 18 animals for regression analysis only.

Statistical analysis. All measurements were compared at each of the three levels of $\mathrm{PaCO}_{2}$ by analysis of variance for repeated measures. Comparisons resulting in a significant $\mathrm{F}$ value were further evaluated by the Newman-Keuls multiple range test. Regression analyses were performed on a CLINFO computer by least-squares.

\section{RESULTS}

Right and left hemispheric blood flows were compared for all $54(18 \times 3)$ microsphere injections by analysis of variance. There was no significant difference between right and left hemispheric blood flows indicating adequate mixing of microspheres and no detectable disturbance of blood flow by the carotid catheter.

Due to variations in gas flow rates, the $\mathrm{PaCO}_{2}$ was not maintained at exactly 40,25, and 15 torr. Mean $\mathrm{PaCO}_{2}( \pm \mathrm{SD})$ for the three levels was $42.2 \pm 3.7,27.7 \pm 2.3$ and $13.2 \pm 2.8$ torr. Table 1 lists physiologic variables including arterial and sagittal sinus blood gases, hematocrits and $\mathrm{O}_{2}$ contents for each of the three periods. Despite a decrease in $\mathrm{PaO}_{2}$ at 25 and 15 torr $\mathrm{CO}_{2}$, the arterial $\mathrm{O}_{2}$ content was stable as was the hematocrit. $\mathrm{PaO}_{2}$ measurements would be expected to decrease with progressive hypocarbia due to the leftward shift of the oxyhemoglobin dissociation curve seen with hypocarbia (17).

Mean values for arterial blood pressure and cardiac output are also seen in Table 1. Mean arterial blood pressure was $10 \%$ lower 
at a $\mathrm{PaCO}_{2}$ of 15 torr compared to 40 torr $\mathrm{PaCO}_{2}(p<0.05)$. Blood pressure at a $\mathrm{PaCO}_{2}$ of 25 torr was not different from either 15 or 40 torr $\mathrm{PaCO}_{2}$. Compared to normocarbia, cardiac output fell significantly when the $\mathrm{PaCO}_{2}$ was $25(p<0.025)$ and $15(p<0.005)$ torr. There was no change in cardiac output between 25 and 15 torr $\mathrm{PaCO}_{2}$. As the ventilator stroke volume and respiratory rate were not changed during the study, the peak airway pressures remained relatively constant at $11.9 \pm 1.5,11.9$ \pm 1.4 , and $12.4 \pm 1.4 \mathrm{~cm} \mathrm{H}_{2} \mathrm{O}$ at $\mathrm{PaCO}_{2}$ values of 40,25 , and 15 torr, respectively.

Table 2 lists $\mathrm{CBF}, \mathrm{rCBF},(\mathrm{A}-\mathrm{V}) \mathrm{O}_{2}$, and $\mathrm{CMRO}_{2}$ at each level of $\mathrm{PaCO}_{2}$. Compared to normocarbia, all blood flows were significantly reduced at $\mathrm{PaCO}_{2}$ values of $25(p<0.001)$ and 15 $(p<0.001)$ torr. Mean blood flows for total and all regional samples were lower at a $\mathrm{PaCO}_{2}$ of 15 compared to 25 torr with only brainstem and thalamic flows $(0.10>p>0.05)$ failing to reach the $p<0.05$ level of significance. Cerebral oxygen transport (total hemispheric flow $\times$ arterial oxygen content) fell significantly $(p<0.001)$ at each level of hypocarbia. Cerebral oxygen extraction increased with progressive hypocarbia, i.e. $(\mathrm{A}-\mathrm{V}) \mathrm{O}_{2}$ and the percent extraction at each level of $\mathrm{PaCO}_{2}$ was significantly different from the other two $(p<0.001)$. Since $(A-V) \mathrm{O}_{2}$ measured at the sagittal sinus does not reflect brainstem or cerebellar extraction, $\mathrm{CMRO}_{2}$ was calculated as $(\mathrm{A}-\mathrm{V}) \mathrm{O}_{2} \times$ hemispheric blood flow. $\mathrm{CMRO}_{2}$ fell by $14.8 \%$ at a $\mathrm{PaCO}_{2}$ of 25 torr $(p<0.05)$ and $18.8 \%$ at a $\mathrm{PaCO}_{2}$ of 15 torr $(p<0.025)$.
Figure 1 depicts all 72 total and rCBF measurements in 24 animals plotted against $\mathrm{PaCO}_{2}$. Regression equations, $R$ and $p$ values are listed in Table 3 .

\section{DISCUSSION}

The current study clearly demonstrates that progressive decreases in $\mathrm{PaCO}_{2}$ are associated with progressive decreases in total $\mathrm{CBF}$ even beneath a $\mathrm{PaCO}_{2}$ of 25 torr. Moreover, the observed decreases in total $\mathrm{CBF}$ were reflected in decreases in each of the $\mathrm{rCBF}$ examined. Total $\mathrm{CBF}$ has been reported during moderate hypocarbia in newborn dogs by both Hernandez et al. (18) and Gregoire et al. (11). Our reported value of $18 \mathrm{ml} / 100$ $\mathrm{g} / \mathrm{min}$ compares well with the reported value of Hernandez et al. (18) of $16 \mathrm{ml} / 100 \mathrm{~g} / \mathrm{min}$ at a $\mathrm{PaCO}_{2}$ of 28 torr, although his normocarbic value of $23 \mathrm{ml} / 100 \mathrm{~g} / \mathrm{min}$ is much lower than ours. Gregoire et al. (11) reported a higher value of $38 \mathrm{ml} / 100 \mathrm{~g} / \mathrm{min}$ at a $\mathrm{PaCO}_{2}$ of 31 torr. It should be noted that although both investigators modified the Kety and Schmidt $(22,23)$ technique by using $133-\mathrm{Xe}$ as an indicator, they determined quite different blood-brain partition coefficients of 0.51 and 0.74 . This difference in partition coefficients explains a large portion of the differences in their reported values for CBF. Our data compares very well with that of Cartwright et al. (1) who also used the microsphere technique to measure total $\mathrm{CBF}$ at $\mathrm{PaCO}_{2}$ values of 38 and 22 torr. In that study, $\mathrm{CBF}$ fell from a normocarbic value of 40 to $22 \mathrm{ml} / 100 \mathrm{~g} / \mathrm{min}$ during hyperventilation.

Table 1. Physiologic variables at $\mathrm{PaCO}_{2}$ values of 40,25 , and 15 torr (mean $\pm S D, n=18$ )

\begin{tabular}{|c|c|c|c|c|}
\hline & & \multicolumn{3}{|c|}{$\mathrm{PaCO}_{2}$ level } \\
\hline & & 40 torr & 25 torr & 15 torr \\
\hline $\mathrm{pH}$ & Arterial & $7.33 \pm 0.06$ & $7.50 \pm 0.06^{*}$ & $7.71 \pm 0.07^{*}$, \\
\hline $\mathrm{PaCO}_{2}$ & Arterial & $42.9 \pm 3.7$ & $27.7 \pm 2.3^{*}$ & $13.2 \pm 2.8^{*} \dagger$ \\
\hline $\mathrm{PaO}_{2}$ & Arterial & $130 \pm 56$ & $111 \pm 48 \ddagger$ & $80 \pm 33^{*} \dagger$ \\
\hline Base excess & Arterial & $-3.7 \pm 4.1$ & $1.1 \pm 3.7^{*}$ & $3.8 \pm 4.3^{*}+$ \\
\hline Hematocrit (\%) & Arterial & $47.9 \pm 4.5$ & $48.2 \pm 5.2$ & $47.9 \pm 5.4$ \\
\hline $\mathrm{O}_{2}$ Content (vol\%) & Arterial & $16.0 \pm 2.5$ & $16.3 \pm 2.9$ & $16.4 \pm 2.6$ \\
\hline $\mathrm{pH}$ & Sagittal & $7.30 \pm 0.05$ & $7.42 \pm 0.05^{*}$ & $7.57 \pm 0.06^{*, \dagger}$ \\
\hline $\mathrm{PvCO}_{2}$ & Sagittal & $46.5 \pm 5.8$ & $35.2 \pm 3.2^{*}$ & $22.8 \pm 3.7^{*+} \uparrow$ \\
\hline $\mathrm{PvO}_{2}$ & Sagittal & $53.3 \pm 18.4$ & $34.3 \pm 9.4^{*}$ & $23.6 \pm 8.3^{*} \uparrow$ \\
\hline Base excess & Sagittal & $-4.9 \pm 3.9$ & $0 \pm 3.5^{*}$ & $2.9 \pm 3.5^{*} \dagger$ \\
\hline Cardiac output $(\mathrm{ml} / \mathrm{Kg} / \mathrm{min})$ & & $169 \pm 71$ & $135 \pm 27 \ddagger$ & $127 \pm 36 \ddagger$ \\
\hline Blood pressure $(\mathrm{mm} \mathrm{Hg})$ & & $55.8 \pm 11.3$ & $53.4 \pm 12.4$ & $50.5 \pm 11.9 \ddagger$ \\
\hline
\end{tabular}

$* p<0.001$ compared to 40 torr.

$\dagger p<0.001$ compared to 25 torr.

$\ddagger p<0.05$ compared to 40 torr.

Table 2. Regional CBFs and indices of cerebral $\mathrm{O}_{2}$ metabolism at $\mathrm{PaCO}$ levels of 40,25 , and 15 torr $($ mean $\pm S D, n=18)$

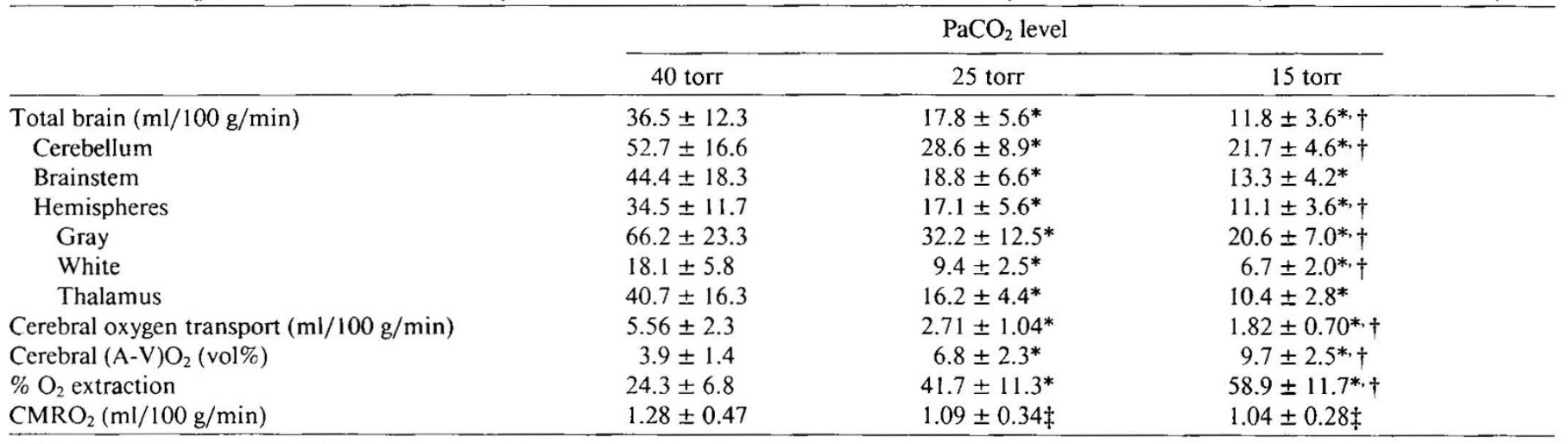

$* p<0.001$ compared to 40 torr

$\dagger p<0.05$ compared to 25 torr.

$\ddagger p<0.05$ compared to 40 torr. 


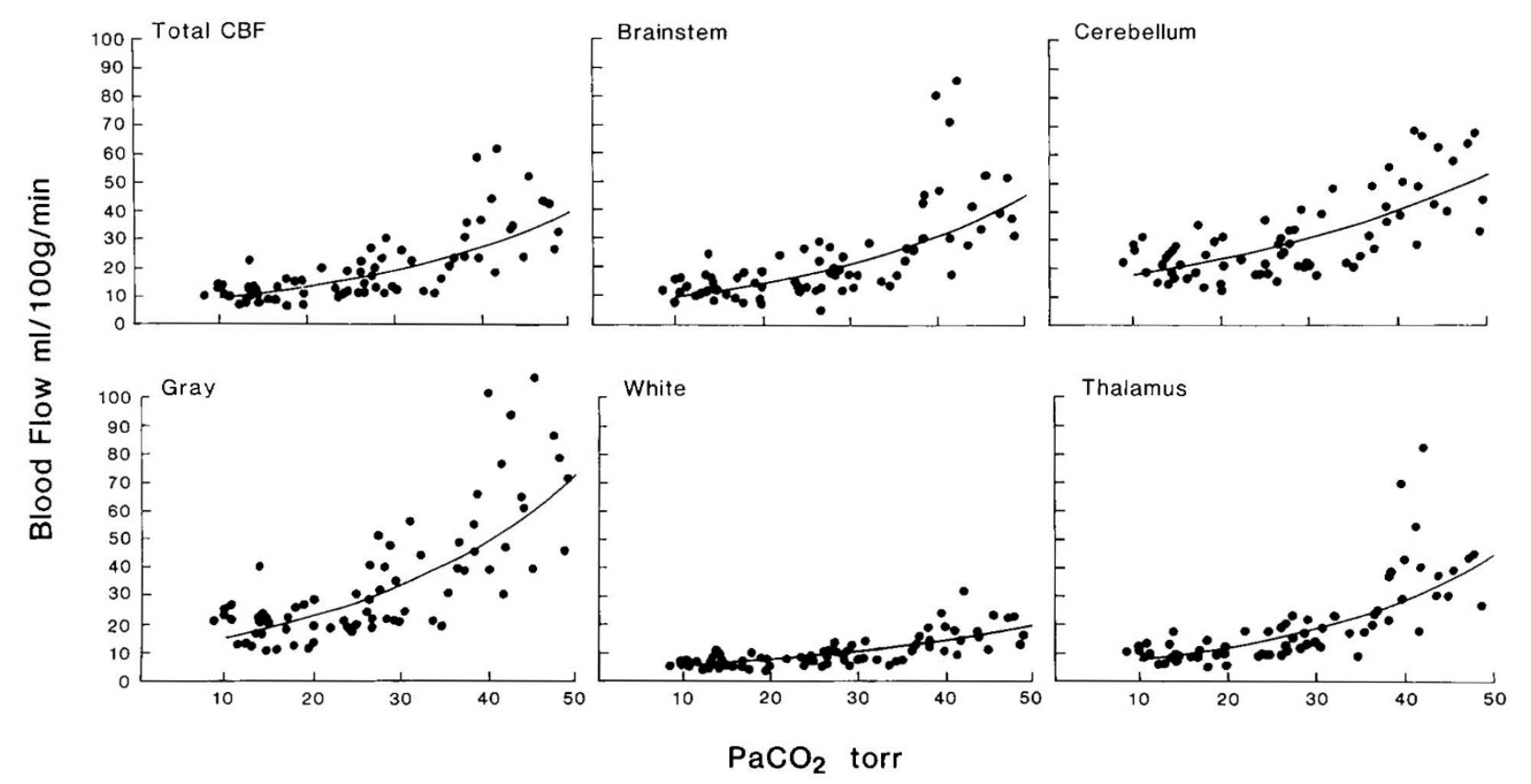

Fig. 1. Relationship between $\mathrm{PaCO}_{2}$ and total and $\mathrm{rCBF}$ between 10 and 50 torr. Regression equations, $R$ and $p$ values are listed in Table 3 . Regression curves were generated by taking the antilogs of the solutions to the regression equations.

Table 3. Regression equations and $\mathrm{R}$ values for $\mathrm{PaCO}$ vs $r C B F$

\begin{tabular}{llccc}
\hline Equation & $n$ & $R$ & $p$ \\
\hline In total $\mathrm{CBF}$ & $=1.89+0.036 \mathrm{PaCO}_{2}$ & 72 & 0.78 & $<0.001$ \\
ln brainstem & $=1.94+0.037 \mathrm{PaCO}_{2}$ & 72 & 0.74 & $<0.001$ \\
ln cerebellum & $=2.63+0.027 \mathrm{PaCO}_{2}$ & 72 & 0.69 & $<0.001$ \\
ln gray & $=2.39+0.038 \mathrm{PaCO}_{2}$ & 72 & 0.78 & $<0.001$ \\
In white & $=1.39+0.032 \mathrm{PaCO}_{2}$ & 72 & 0.77 & $<0.001$ \\
ln thalamus & $=1.64+0.043 \mathrm{PaCO}_{2}$ & 69 & 0.81 & $<0.001$ \\
\hline
\end{tabular}

Shapiro et al. (2) provide the only previous data for $\mathrm{rCBF}$ during hypocarbia in the newborn dog. Using a $\left[{ }^{14-C}\right]$ antipyrine autoradiographic technique, they reported $\mathrm{rCBF}$ to the cortical gray and subcortical white matter at a $\mathrm{PaCO}_{2}$ of 22 torr to be 22.5 and $6 \mathrm{ml} / 100 \mathrm{~g} / \mathrm{min}$, respectively. In contrast to Shapiro et al. (2) who did not find a significant reduction in gray matter flow below a $\mathrm{PaCO}_{2}$ of 36 torr, the present study demonstrated significant reductions in total as well as cortical gray and white matter flows between $\mathrm{PaCO}_{2}$ values of 25 and 15 torr. Our data do not support the suggestion of Shapiro et al. (2) that the newborn mammal has a higher threshold $\mathrm{PaCO}_{2}$ which would thereby limit $\mathrm{CBF}$ reduction during severe hypocarbia.

The nonlinearity of the $\mathrm{PaCO}_{2}$ versus $\mathrm{CBF}$ relationship between $\mathrm{PaCO}_{2}$ values of 10 and 50 torr is demonstrated for total as well as $\mathrm{rCBF}$. The linear relationship described by Shapiro et al. (2) was between 22 and 65 torr $\mathrm{CO}_{2}$. The weight of our data points between $\mathrm{PaCO}_{2}$ values of 10 to 22 torr contributes heavily to the nonlinear relationship. A nonlinear relationship between $\mathrm{PaCO}_{2}$ and total $\mathrm{CBF}$ is consistent with data from adult dogs (19) and from the piglet (4). Our data differ from the study by Hansen et al. (4) in the piglet in that we observed significant reactivity of the hindbrain structures to hypocarbia.

$\mathrm{CMRO}_{2}$ measurements in the newborn dog at normocarbia found in the current study are similar to the $1.13 \mathrm{ml} / 100 \mathrm{~g} / \mathrm{min}$ of Hernandez et al. (18) and somewhat lower than $2.15 \mathrm{ml} / 100$ $\mathrm{g} / \mathrm{min}$ reported by Gregoire et al. (11). The $\mathrm{CMRO}_{2}$ measurements by Hernandez et al. (18) and Gregoire et al. (11) are also influenced by their different Xenon partition coefficients as was just discussed. $\mathrm{CMRO}_{2}$ for adult dogs have been reported at 3-4 $\mathrm{ml} / 100 \mathrm{~g} / \mathrm{min}$, twice that of the newborn $\operatorname{dog}(8,20)$. Newborn lambs studied by Rosenberg et al. (5) had $\mathrm{CMRO}_{2}$ values equal to or greater than those in adult sheep. The reason for the low $\mathrm{CMRO}_{2}$ in the newborn dog is likely due to its CNS immaturity at birth.

Adult studies in both animals $(8,20)$ and humans (21-23) suggest that $\mathrm{CMRO}_{2}$ is maintained constant during severe hypocarbia. Other neonatal studies in which $\mathrm{CMRO}_{2}$ has been evaluated during a significant degree of hypocarbia were performed using fetal and newborn lambs and piglets. Gregory et al. (3), in an abstracted report, did not find a significant decrease in $\mathrm{CMRO}_{2}$ in newborn lambs when $\mathrm{PaCO}_{2}$ was lowered to 22 torr. Similarly, Rosenberg et al. (5) found no correlation between $\mathrm{CMRO}_{2}$ and $\mathrm{PaCO}_{2}$ in fetal and newborn lambs when $\mathrm{PaCO}_{2}$ was varied between 25 and 70 torr. A recent report observed the newborn piglet to have a decrease in $\mathrm{CMRO}_{2}$ after $30 \mathrm{~min}$ of hyperventilation but $\mathrm{CMRO}_{2}$ returned to baseline by $1 \mathrm{~h}$ during continued hyperventilation (24). Although species difference may explain the difference in $\mathrm{CMRO}_{2}$ response between lambs and newborn dogs, a more likely explanation would be the difference in neurologic maturity at birth. Comparing sensorymotor function, the lamb would appear to be significantly more mature than the newborn dog at birth. Histologically, the brain of the newborn dog at term gestation has a germinal matrix $(25)$ and the cortical gray matter demonstrates minimal stratification of neuronal layers at birth (Reuter JH, personal observation).

Although it may be tempting to attribute the decrease in $\mathrm{CMRO}_{2}$ solely to the large decreases in $\mathrm{CBF}$ and oxygen transport to the brain during hypocarbia, this is not the only possible interpretation of the data. There was no increase in base deficit in sagittal sinus blood during hypocarbia, this could be taken as evidence against cerebral hypoxia and increased anaerobic glycolysis. Also, the $15 \%$ decrease in $\mathrm{CMRO}_{2}$ during hypocarbia occurred despite the fact that cerebral venous blood was still at least $50 \%$ saturated $\left(\mathrm{PvO}_{2} 24-34\right.$ torr); this would suggest that there may be a reduced demand for $\mathrm{O}_{2}$. Hypocarbia, with large increases in $\mathrm{pH}$, may possibly have an effect on cerebral metabolism, thus reducing the demand for $\mathrm{O}_{2}$ uptake. Alkalosis has been shown to diminish respiration in mitochondria isolated from avian cardiac muscle (26). Similarly, Howell et al. (27) have recently discussed a possible role of alkalosis in inhibition of oxidative phosphorylation. 
CSF and brain lactate levels increase during hyperventilation, however, the etiology of this increase in lactate remains unclear. Alkalosis alone is thought to increase lactate production by stimulating the activity of phosphofructokinase (28). Huckabee (29) has proposed that lactic acid production may be a mechanism of acid-base homeostasis by reducing body bicarbonate during alkalosis. Alternately, Plum et al. (30) have observed decreased cerebral lactate accumulation in dogs hyperventilated under hyperbaric-hyperoxic conditions, thus suggesting hypoxia may be at least contributing to lactate accumulation during hypocarbia. Regardless of the etiology, there remains the question as to whether an immature brain is adversely affected by lactic acid. Results of several laboratories do suggest adverse effects of lactic acid on the CNS (31-33).

At the onset of hypocarbia, it was common to observe a significant decrease in blood pressure which then gradually returned toward baseline. This observation has been reported previously in adult humans (34). The small (10\%) but statistically significant drop in blood pressure we observed indicates baseline blood pressure had not been achieved after $30 \mathrm{~min}$ of hypocarbia ( $\mathrm{PaCO}_{2}$ of 15 torr).

The 20 and $25 \%$ decreases in cardiac output found at $\mathrm{PaCO}_{2}$ values of 25 and 15 torr, respectively, is a new finding in newborn dogs. This decrease cannot be attributed to changes in ventilatory pattern since neither respirator rate or volume were changed. Unfortunately, we do not have measurements of heart rate, central venous pressure, or an index of myocardial contractility to further characterize this decrease in cardiac output. Cartwright et al. (1) did not report a significant fall in cardiac output during hyperventilation to a $\mathrm{PaCO}_{2}$ of 22 torr. Although their mean cardiac output measurement fell by $84 \mathrm{ml} / \mathrm{kg} / \mathrm{min}$ after $2 \mathrm{~h}$ of hyperventilation, the number of animals studied $(n=6)$ may not have rendered adequate statistical strength. Cartwright $e t$ al. (1) did, however, report a significant decrease in myocardial blood flow during hypocarbia. Studies in anesthesized adult dogs have demonstrated both decreases $(35,36)$ and no change $(37)$ in cardiac output in response to hypocarbia induced by passive hyperventilation.

It must be stressed that the findings of the current study were derived from experiments in which there was only a short period of hypocarbia. Work in piglets suggests the decrease in $\mathrm{CMRO}_{2}$ may be a transient observation (24). Our measurements of $\mathrm{CMRO}_{2}$ are, obviously, estimates of aerobic metabolism only; possible anaerobic contributions to cerebral metabolism during hypocarbia in the newborn dog await further study.

In conclusion, there is a nonlinear positive relationship between $\mathrm{PaCO}_{2}$ and $\mathrm{rCBF}$ from $\mathrm{PaCO}_{2}$ values of 10 to 50 torr in the newborn dog. The cerebral metabolic rate of oxygen is also reduced by hyperventilation to $\mathrm{PaCO}_{2}$ values of 25 and 15 torr. Whether the decrease in $\mathrm{CMRO}_{2}$ is due to the decrease in oxygen delivery or to a decrease in oxygen demand cannot be precisely determined from the present data. On the basis of sagittal sinus blood having 1) an oxygen saturation of approximately $50 \%$ and 2) no increase in base deficit, we speculate the observed decrease in $\mathrm{CMRO}_{2}$ during respiratory alkalosis may be due to a decrease in cerebral oxygen demand.

Acknowledgments. The authors thank Drs. R. Banks, E. Donovan, and U. Kotagal for their suggestions in preparation of this manuscript and Mrs. Phyllis Downey for her secretarial assistance.

\section{REFERENCES}

1. Cartwright D, Gregory GA, Lou H, Heymann MA 1984 The effect of hypocarbia on the cardiovascular system of puppies. Pediatr Res 18:685-690

2. Shapiro HM, Greenberg JH, Van Horn Naughton K, Reivich M, 1980 Het erogeneity of local cerebral blood flow $-\mathrm{P}_{\mathrm{a}} \mathrm{CO}_{2}$ sensitivity in neonatal dogs. J Appl Physiol 49:113-118

3. Gregory GA, Ong W, Tweed A, Wade JG 1982 The effects of severe alkalosis and hypoxemia on cerebral metabolism in the newborn lamb. Anesthesiology 57:A424
4. Hansen NB, Brubakk AM, Bratlid D, Oh W, Stonestreet BS 1984 The effects of variations in $\mathrm{PaCO}_{2}$ on brain blood flow and cardiac output in the newborn piglet. Pediatr Res 18:1132-1136

5. Rosenberg AA, Jones MD Jr, Traystman RJ, Simmons MA, Molteni RA 1982 Response of cerebral blood flow to changes in $\mathrm{PCO}_{2}$ in fetal, newborn, and adult sheep. Am J Physiol 242:H862-866

6. Kennealy JA, McLennan JE, Loudon RG, McLaurin RL 1980 Hyperventilation induced cerebral hypoxia. Am Rev Respir Dis 122:407-412

7. Sugioka K, Davis DA 1960 Hyperventilation with oxygen-a possible cause of cerebral hypoxia. Anesthesiology 21:135-143

8. Alberti E, Hoyer S, Hamer J, Stoeckel H, Packschiess P, Weinhardt F 1975 The effect of carbon dioxide on cerebral blood flow and cerebral metabolism in dogs. Br J Anaesth 47:941-946

9. Plum F, Posner JB 1967 Blood and cerebrospinal fluid lactate during hyperventilation. Am J Physiol 212:864-870

10. Alexander SC, Cohen PJ, Wollman H, Smith TC, Reivich M, Vander Molen RA 1965 Cerebral carbohydrate metabolism during hypocarbia in man. Anesthesiology 26:624-632

11. Gregoire NM, Gjedde A, Plum F, Duffy TE 1978 Cerebral blood flow and cerebral metabolic rates for oxygen, glucose, and ketone bodies in newborn dogs. J Neurochem 30:63-69

12. Reuter JH, Phibbs RH 1981 Cerebral and germinal matrix blood flow in the newborn dog. Clin Res 29:144A(abstr)

13. Heymann MA, Payne DB, Hoffman JIE, Rudolph AM 1977 Blood flow measurements with radionuclide-labeled particles. Prog Cardiovasc Dis 20:55-79

14. Buckberg GD, Luck JC, Payne DB, Hoffman JIE, Archie JP, Fixler DE 1971 Some sources of error in measuring regional blood flow with radioactive microspheres. J Appl Physiol 31:598-604

15. Evans HE, Christensen GC 1979 Miller's Anatomy of the Dog. WB Saunders Co, Philadelphia, pp 656-671

16. Aukland K, Bower BF, Berliner RW 1964 Measurement of local blood flow with hydrogen gas. Circ Res 14:164-187

17. Roughton FJW 1964 Transport of oxygen and carbon dioxide. In: Fenn WO, Rahn H (eds) Handbook of Physiology, Respiration, Vol 1. Williams \& Wilkins, Baltimore, pp 776

18. Hernandez MJ, Brennan RW, Vannucci RC, Bowman GS 1978 Cerebral blood flow and oxygen consumption in the newborn dog. Am J Physio 234:R209-215

19. Harper AM 1965 The inter-relationship between $\mathrm{aPCO}_{2}$ and blood pressure in the regulation of blood flow through the cerebral cortex. Acta Neurol Scand 41(suppl 14):94-103

20. Raichle ME, Posner JB, Plum F 1970 Cerebral blood flow during and after hyperventilation. Arch Neurol 23:394-403

21. Wasserman AJ, Patterson JL 1961 The cerebral vascular response to reduction in arterial carbon dioxide tension. J Clin Invest 40:1297-1303

22. Kety SS, Schmidt CF 1948 The effects of altered arterial tensions of carbon dioxide and oxygen on cerebral blood flow and cerebral oxygen consumption of normal young men. J Clin Invest 27:484-492

23. Kety SS, Schmidt CF 1946 The effects of active and passive hyperventilation on cerebral blood flow, cerebral oxygen consumption, cardiac output, and blood pressure of normal young men. J Clin Invest 25:107-119

24. Hansen NB, Nowicki PT, Miller RR, Malone T, Bickers RG, Menke JA 1986 Alterations in cerebral blood flow and oxygen consumption during prolonged hypocarbia. Pediatr Res 20:147-150

25. Goddard J, Lewis RM, Alcala H, Zeller RS 1980 Intraventricular hemorrhage - an animal model. Biol Neonate 37:39-52

26. Lowenstein JM, Chance B 1968 The effect of hydrogen ions on the control of mitochondrial respiration. J Biol Chem 243:3940-3946

27. Howell S, Fitzgerald RS, Roussos C 1985 Effects of uncompensated and compensated metabolic acidosis on canine diaphragm. J Appl Physiol 59:1376-1382

28. Scheuer J, Berry MN 1967 Effect of alkalosis on glycolysis in the isolated rat heart. Am J Physiol 213:1 143-1148

29. Huckabee WE 1958 Relationships of pyruvate and lactate during anaerobic metabolism. I. Effects of infusion of pyruvate or glucose and of hyperventilation. J Clin Invest 37:244-254

30. Plum F, Posner JB, Smith WW 1968 Effect of hyperbaric-hyperoxic hyperventilation on blood, brain, and CSF lactate. Am J Physiol 21 5:1240-1244

31. Myers RE 1979 Lactic acid accumulation as a cause of brain edema and cerebral necrosis resulting from oxygen deprivaton. In: Korobkin R, Guilleminault C (eds) Advances in Perinatal Neurology. Spectrum Publishers, New York, pp 84-114

32. Pulsinelli WA, Waldman S, Rawlinson D, Plum F 1982 Hyperglycemia converts ischemic neuronal damage into brain infarction. Neurology 32:12391246

33. Friede R, Van Houten W 1961 Relations between post mortem alterations and glycolytic metabolism in the brain. Exp Neurol 4:197-204

34. Richardson DW, Kontos HA, Raper AJ, Patterson JL 1972 Systemic circulatory responses to hypocapnia in man. Am J Physiol 223:1308-1312

35. Marshall M, Williams WG, Creighton RE, Volgyesi GA, Steward DJ 1976 A technique for measuring regional myocardial blood flow and its application in determining the effects of hyperventilation and halothane. Can Anaesth Soc J 23:244-251

36. Little RC, Smith CW 1964 Cardiovascular response to acute hypocapnia due to overbreathing. Am J Physiol 206:1025-1030

37. Rowe GG, Castillo CA, Crumpton CW 1962 Effects of hyperventilation on systemic and coronary hemodynamics. Am Heart J 63:67-77 